\title{
Induction of Nitric Oxide Synthase by Cyclic AMP in Rat Vascular Smooth Muscle Cells
}

Taihei Imai, Yukio Hirata, Kazuo Kanno, and Fumiaki Marumo

Second Department of Internal Medicine, Tokyo Medical and Dental University, Tokyo 113, Japan

\begin{abstract}
By measurements of $\mathrm{NO}_{2}^{-} / \mathrm{NO}_{3}^{-}$(NOx) production and Northern blot analysis, we studied the effects of a membranepermeable cAMP derivative, 8-bromo-cAMP, on the expression of inducible nitric oxide synthase (iNOS) gene and the synthesis of NOx in cultured rat vascular smooth muscle cells (VSMCs). 8-bromo-cAMP stimulated NOx production and increased steady-state levels of iNOS mRNA in rat VSMC in a time- and dose-dependent manner. $N^{\mathrm{G}}$-monomethyl-L-arginine, a NOS inhibitor, completely blocked the 8-bromocAMP-induced NOx production, whose effect was partially, but significantly reversed by an excess L-arginine, but not by D-arginine. Compounds that increase intracellular cAMP levels (cholera toxin, forskolin, and 3-isobutyl-1-methylxanthine), all stimulated NOx production. Dexamethasone inhibited the stimulated NOx production, as well as the induction of iNOS mRNA by cAMP. Both actinomycin D and cycloheximide completely blocked the stimulated NOx production by cAMP. Actinomycin D abolished the cAMP-induced iNOS mRNA, whereas cycloheximide remarkably increased iNOS mRNA levels in the presence and absence of 8-bromo-cAMP (superinduction). Actinomycin D, but not dexamethasone, completely abolished the cycloheximide-induced iNOS mRNA. The half-life of cAMP-induced iNOS mRNA was $\sim 2$ h, whereas no decay in the cycloheximide-induced iNOS mRNA was observed during $12 \mathrm{~h}$. These results demonstrate that iNOS gene is upregulated by cAMP and the superinduction of iNOS mRNA is attributable to increased mRNA stability in rat VSMC. (J. Clin. Invest. 1994. 93:543-549.) Key words: nitric oxide synthase • induction • cyclic AMP • vascular smooth muscle cells
\end{abstract}

\section{Introduction}

Endothelium-derived relaxing factor has been identified as nitric oxide (NO) ${ }^{1}$ or closely related molecule $(\mathrm{s})$. NO is synthesized from the guanidino nitrogen atom of $\mathrm{L}$-arginine by the catalytic action of enzymes, collectively known as NO syn-

Address correspondence to Yukio Hirata, M.D., Endocrine-Hypertension Division, Second Department of Internal Medicine, Tokyo Medical and Dental University, Yushima 1-5-45, Bunkyo-ku, Tokyo 113, Japan.

Received for publication 28 May 1993 and in revised form 17 September 1993.

J. Clin. Invest.

(C) The American Society for Clinical Investigation, Inc.

$0021-9738 / 94 / 02 / 0543 / 07 \quad \$ 2.00$

Volume 93, February 1994, 543-549 thases (NOS) (1). At least two types of enzymes exist; one is $\mathrm{Ca}^{2+} /$ calmodulin-dependent and constitutive (c) NOS mainly present in brain (2) and vascular endothelial cells $(3,4)$, and the other is $\mathrm{Ca}^{2+} /$ calmodulin-independent and cytokine-inducible (i) NOS mainly present in macrophages (5) and vascular smooth muscle cells (VSMCs) (6). Recently, two isoforms of cNOS have been cloned from rat brain (7) and vascular endothelium (8-10). iNOS has also been cloned from activated mouse macrophage cell line (RAW 264.7) (11,12). cNOS and iNOS, both of which are structurally homologous to cytochrome $\mathrm{P} 450$ reductase, have the recognition sites for NADPH, flavin adenine dinucleotide, flavin mononucleotide, and calmodulin. In contrast to the possible phosphorylation site for cAMP-dependent protein kinase (PKA) in brain and endothelial cNOS isoforms, macrophage iNOS lacks the consensus sequence.

Macrophage iNOS is activated by bacterial LPS and several cytokines, such as IL- $1 \beta$, TNF- $\alpha$, and $\operatorname{IFN}-\gamma(6,13,14)$. It has been reported that these cytokines increase accumulation of cGMP in rabbit and rat VSMC, possibly via NO production (6, 15 ). In endotoxin shock, it has been suggested that excessive production of NO stimulated by LPS and cytokines contributes to the development of profound hypotension and hyporesponsiveness of exogenous vasoconstrictors. The induction of iNOS requires de novo protein synthesis over several hours. However, whether a classical intracellular second messenger like cAMP is involved in the process of this induction in VSMC remains unknown. It also remains undetermined whether posttranscriptional modification affects iNOS mRNA stability in the cells. Therefore, the present study was aimed to investigate whether iNOS gene is regulated by cAMP in cultured rat vascular smooth muscle cells, and whether the expression of iNOS mRNA is regulated posttranscriptionally.

\section{Methods}

Materials. 8-bromoadenosine 3':5'-cyclic monophosphate (8-bromocAMP), cholera toxin, forskolin, 3-isobutyl-1-methylxanthine (IBMX), dexamethasone, as well as L- and D-arginine were obtained from Sigma Chemical Co. (St. Louis, MO), $N^{\mathrm{G}}$-monomethyl-L-arginine (LNMMA) from Calbiochem-Novabiochem Corp. (La Jolla, CA), actinomycin D and cycloheximide from Wako Pure Chemical (Osaka, Ja-

1. Abbreviations used in this paper: AMD, actinomycin D; CHX, cycloheximide; cNOS, $\mathrm{Ca}^{2+}$ /calmodulin-dependent and constitutive nitric oxide synthase; DEX, dexamethanose; GADPH, glyceraldheyde3-phosphate dehydrogenase; IBMX, 3-isobutyl-1-methylxanthine; iNOS, $\mathrm{Ca}^{2+} /$ calmodulin-independent and cytokine-inducible nitric oxide synthase; L-NMMA, $N^{\mathrm{G}}$-monomethyl-L-arginine; NO, nitric oxide; NOS, nitric oxide synthase; NOx, nitrite and nitrate; PKA, cAMPdependent protein kinase; VSMC, vascular smooth muscle cell. 
pan), DME from Flow Laboratories (Irvine, Scotland), FBS from Cell Culture Laboratories (Cleveland, $\mathrm{OH}$ ), deoxycytidine 5'-[ $\left.{ }^{32} \mathrm{P}\right]-$ triphosphate $\left(\left[{ }^{32} \mathrm{P}\right] \mathrm{dCTP}\right)$ from DuPont NEN Research Products (Boston, MA). All other compounds were reagent or molecular biology grade. cDNA probe for human glyceraldehyde-3-phosphate dehydrogenase (GAPDH) was obtained from the American Type Culture Collection (ATCC no. 57091) (Rockville, MD).

Cell culture and incubation. VSMCs were isolated from thoracic aorta of adult Wistar rats by the enzymatic dissociation technique and cultured in DME containing $10 \%$ FBS and antibiotics at $37^{\circ} \mathrm{C}$ in a humidified atmosphere of $95 \%$ air $/ 5 \% \mathrm{CO}_{2}$ as previously described (16). Subcultured VSMCs from the 10th to 20th passages were used in the experiments.

To study the production of nitrite and nitrate (NOx), confluent VSMCs $\left(5 \times 10^{6}\right.$ cells $)$ in six-well dishes (Costar Corp., Cambridge, MA) were usually incubated for $12 \mathrm{~h}$ unless otherwise stated. After incubation, media were removed for NOx measurement.

Determination of $\mathrm{NOx}\left(\mathrm{NO}_{2}^{-} / \mathrm{NO}_{3}^{-}\right)$. Concentrations of $\mathrm{NOx}$ in cultured media were determined by an autoanalyzer (TCI-NOx 1000; Tokyo Kasei Kogyo Co., Tokyo, Japan) as recently reported (17). Briefly, samples were passed through a copperized cadmium reduction column where $\mathrm{NO}_{3}^{-}$was reduced to $\mathrm{NO}_{2}^{-}$, which reacts with Griess reagent ( $1 \%$ sulfonamide $/ 0.1 \% \mathrm{~N}-1$-naphthylethylenediamine dihydrochloride $/ 5 \% \mathrm{HCl}$ ) to form a purple azo dye. The absorbance at 540 $\mathrm{nm}$ was detected by a flow-through visible spectrophotometer (model S/3250; Somakogaku, Tokyo, Japan ).

Preparation of $c D N A$ probe for iNOS. iNOS cDNA probe for Northern blot analysis was prepared by PCR as reported (18). Antisense and sense oligonucleotides of PCR primers for mouse iNOS were synthesized according to the sequences (GATCAGGAACCTGAAGCCCC and GCCCTTTTTTGCCCCATAGG) corresponding to amino acid residues $942-948$ and $1127-1134$, respectively (12). The PCR products were amplified using mouse liver total RNA by 40 cycles of denaturing at $94^{\circ} \mathrm{C}$ for $1 \mathrm{~min}$, annealing at $60^{\circ} \mathrm{C}$ for $1.5 \mathrm{~min}$, and extension at $72^{\circ} \mathrm{C}$ for $2 \mathrm{~min}$. The expected size of PCR product ( 577 bp) was ligated into the pGEM-3Zf $\left({ }^{-}\right)$plasmid vector (Promega Biotec, Madison, WI) by T/A cloning method (19). Nucleotide sequence of the subcloned cDNA was determined by the dideoxy chain termination method (20), which coincided with that of iNOS as reported (12). An insert of BamHI-EcoRI restriction fragment of iNOS plasmids was used as a probe for Northern blot analysis.

RNA preparation and Northern blot analysis. Confluent VSMC monolayers $\left(1.5 \times 10^{7}\right.$ cells) in 60 -mm culture dishes (Falcon Labware, Oxnard, CA) preincubated in serum-free DME for $24 \mathrm{~h}$ were usually incubated in $2 \mathrm{ml}$ fresh serum-free DME with or without compounds for $6 \mathrm{~h}$. For measurement of iNOS mRNA stability, cells were incubated with either 8-bromo-cAMP $\left(10^{-3} \mathrm{M}\right)$ or cycloheximide (1 $\mu \mathrm{g} / \mathrm{ml})$ for $6 \mathrm{~h}$, after which actinomycin $\mathrm{D}(1 \mu \mathrm{g} / \mathrm{ml})$ was added to stop transcription, and the cells were harvested for the indicated times.

Total cellular RNA was extracted by the acid guanidinium thiocyanate-phenol-chloroform method (21). Northern blot analysis was carried out essentially as previously described (22). Total RNA (20 $\mu \mathrm{g})$ was separated by formaldehyde $/ 1.1 \%$ agarose gel electrophoresis and transferred to a nylon membrane (Magnagraph; Micron Separations Inc., Westborough, MA). The cDNA probes for mouse iNOS and human GAPDH were labeled with $\left.{ }^{32} \mathrm{P}\right] \mathrm{dCTP}(111 \mathrm{TBq} / \mathrm{mmol})$ by random-primed labeling method. After ultraviolet wave crosslinking, RNA immobilized on the membrane was hybridized with the labeled probes in the presence of $50 \%$ formamide at $42^{\circ} \mathrm{C}>16 \mathrm{~h}$. The membrane was washed finally in $0.1 \times \operatorname{SSPE}(15 \mathrm{mM} \mathrm{NaCl}, 1 \mathrm{mM}$ $\mathrm{NaH}_{2} \mathrm{PO}_{4}, 0.1 \mathrm{mM}$ ethylenediaminetetraacetic acid ) $/ 0.5 \%$ sodium dodecyl sulfate at $37^{\circ} \mathrm{C}$, and autoradiographed with intensifying screens at $-80^{\circ} \mathrm{C}$. Radioactivities of the membranes were measured by an imaging analyzer (BAS2000; Fuji Photo Film Co. Ltd., Tokyo, Japan).

Statistical analysis. Data are expressed as mean \pm SE. Statistical analysis was performed by unpaired Student's $t$ test. $P<0.05$ was considered statistically significant.

\section{Results}

As shown in Fig. $1 A$, 8-bromo-cAMP $\left(10^{-3} \mathrm{M}\right)$ stimulated NOx production in rat VSMC in a time-dependent manner; about 8-13-fold increases over control levels were observed during 6-24 $\mathrm{h}$ incubation. Northern blot analysis of rat VSMC RNA with mouse iNOS cDNA as a probe revealed a single hybridizing band corresponding to the size of mouse iNOS mRNA (4.4 kb) (Fig. $1 \mathrm{~B})$; 8-bromo-cAMP $\left(10^{-3} \mathrm{M}\right)$ increased steady-state levels of iNOS mRNA after $6 \mathrm{~h}$, which further increased after $24 \mathrm{~h}$ incubation.

8-Bromo-cAMP significantly increased NOx production in a dose-dependent manner $\left(10^{-4}-10^{-3} \mathrm{M}\right)$ (Fig. $2 \mathrm{~A}$ ); about twofold $\left(10^{-4} \mathrm{M}\right)$ and fourfold $\left(10^{-3} \mathrm{M}\right)$ increases over control levels during $12 \mathrm{~h}$ incubation. 8-bromo-cAMP also dose dependently increased steady-state iNOS mRNA levels (Fig. 2 $B$ ); a maximal effect was induced with $10^{-3} \mathrm{M}$.

To determine whether NOS is activated by 8-bromocAMP, the effects of a specific NOS inhibitor (L-NMMA), Land D-arginine on 8-bromo-cAMP-induced NOx production were studied (Fig. 3). L-NMMA $\left(10^{-3} \mathrm{M}\right)$ completely blocked the 8-bromo-cAMP-induced NOx production, whose effect was partially but significantly $(P<0.05)$ reversed by an excess
A

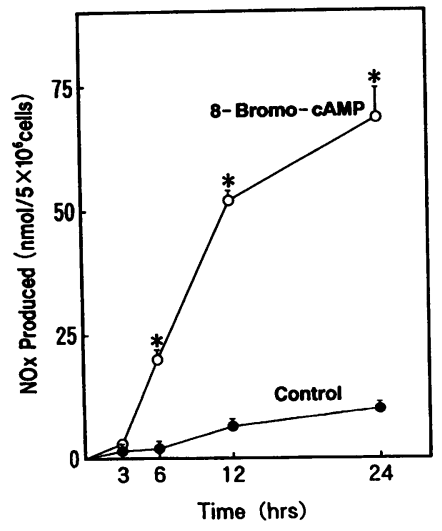

B

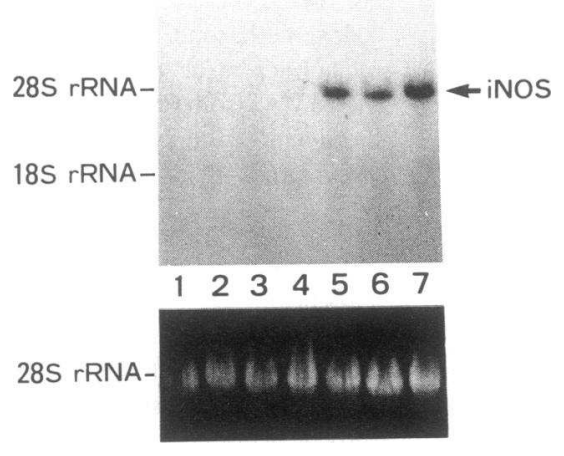

Figure 1. Effect of 8-bromo-cAMP on NOx production and iNOS mRNA expression in rat vascular smooth muscle cells as a function of time. $(A)$ VSMCs were incubated with $(O)$ or without $(\bullet)$ 8-bromo$\operatorname{cAMP}\left(10^{-3} \mathrm{M}\right)$ for the time indicated for measurement of NOx. Each point is the mean of three experiments; bar indicates SE. ${ }^{*} P<0.05$ vs control. $(B)$ Northern blot analysis of iNOS mRNA; total cellular RNA ( $20 \mu \mathrm{g}$ ) was hybridized with cDNA for mouse iNOS as a probe (upper panel) and $28 \mathrm{~S}$ ribosomal RNA loaded in each lane is shown as an internal standard (lower panel). Lane 1, control; lane 2, 8bromo-cAMP $\left(10^{-3} \mathrm{M}\right) 1 \mathrm{~h}$; lane $3,3 \mathrm{~h}$; lane $4,6 \mathrm{~h}$; lane $5,12 \mathrm{~h}$; lane $6,24 \mathrm{~h}$. 


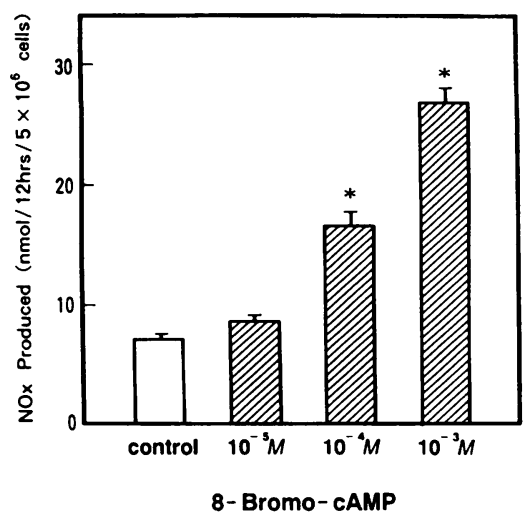

$\left(10^{-2} \mathrm{M}\right)$ L-arginine, but not by $\mathrm{D}$-arginine. L-arginine $(5$ $\left.\times 10^{-3} \mathrm{M}\right)$ also failed to fully reverse the inhibitory effect by lower concentration $\left(5 \times 10^{-4} \mathrm{M}\right)$ of L-NMMA on CAMP-induced NOx production (data not shown).

To determine whether an intracellular cAMP affects NOx production by cultured VSMC, several compounds that increase intracellular cAMP levels, such as IBMX, forskolin, and cholera toxin, were tested. IBMX $\left(10^{-4} \mathrm{M}\right)$, forskolin $\left(10^{-5}\right.$ $\mathrm{M})$, and cholera toxin $(100 \mathrm{ng} / \mathrm{ml})$ stimulated NOx production by 2.5-, 3-, and 6-fold above control levels, respectively (Fig. 4).

Dexamethasone $\left(10^{-7} \mathrm{M}\right)$ completely blocked the 8bromo-cAMP-induced NOx production (Fig. $5 A$ ) and reduced the cAMP-induced iNOS mRNA (Fig. $5 B$ ). Both actinomycin $\mathrm{D}(1 \mu \mathrm{g} / \mathrm{ml})$ and cycloheximide $(1 \mu \mathrm{g} / \mathrm{ml})$ completely blocked the 8-bromo-cAMP-induced NOx production (Fig. 6 $A$ ). Northern blot analysis showed that actinomycin D completely abolished the induction of iNOS mRNA by 8-bromocAMP, whereas cycloheximide remarkably increased the basal, as well as the stimulated iNOS mRNA expression (Fig. $6 \mathrm{~B}$ ). Cycloheximide dose dependently $(0.1-1 \mu \mathrm{g} / \mathrm{ml})$ increased steady-state levels of iNOS mRNA during $6 \mathrm{~h}$ incubation with

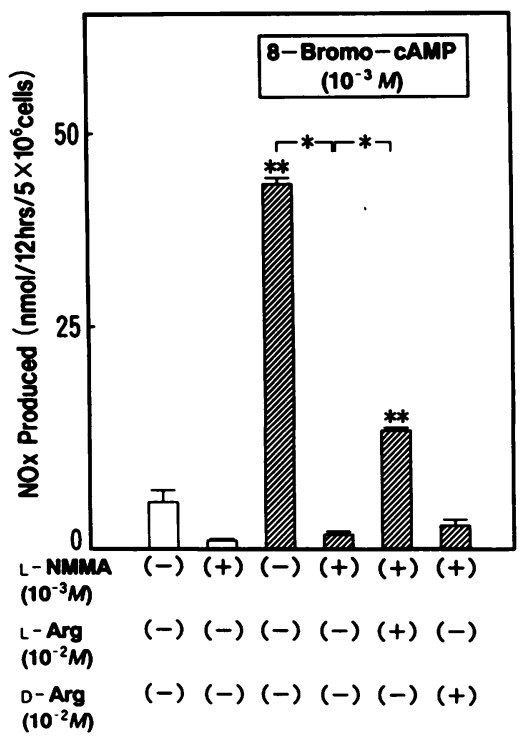

Figure 3. Effects of $N^{\mathrm{G}}$ monomethyl-L-arginine, L- and D-arginine on 8-bromo-cAMP-induced NOx production in rat vascular smooth muscle cells. VSMCs were incubated with $(\square)$ or without $(\square) 8$ bromo-cAMP $\left(10^{-3} \mathrm{M}\right)$ in the absence and presence of L-NMMA $\left(10^{-3}\right.$ $\mathrm{M}), \mathrm{L}$ - and D-arginine $\left(10^{-2} \mathrm{M}\right.$ ) for $12 \mathrm{~h}$; NOx released into medium was measured. Data are plotted in the same as in Fig. $2(n=3) .{ }^{*} P$ $<0.05$ between groups, ${ }^{* *} P<0.05$ vs control. the maximal effective dose of $1 \mu \mathrm{g} / \mathrm{ml}$ (Fig. 7). Actinomycin D ( $1 \mu \mathrm{g} / \mathrm{ml}$ ) completely abolished the cycloheximide-induced iNOS mRNA, but dexamethasone $\left(10^{-7} \mathrm{M}\right)$ failed to affect the cycloheximide-induced iNOS mRNA (Fig. 8).

To determine whether cAMP and cycloheximide increase steady-state iNOS mRNA levels by decreasing its degradation rate, we studied the decay in iNOS mRNA levels induced by 8-bromo-cAMP $\left(10^{-3} \mathrm{M}\right)$ or cycloheximide $(1 \mu \mathrm{g} / \mathrm{ml})$ for $6 \mathrm{~h}$ before the addition of actinomycin $\mathrm{D}(1 \mu \mathrm{g} / \mathrm{ml})$ (Fig. 9). The half-life of iNOS mRNA induced by 8-bromo-cAMP was $\sim 2$ $h$. However, the cycloheximide-induced upregulation of iNOS mRNA remained unaltered during $12 \mathrm{~h}$.

\section{Discussion}

The present study has clearly demonstrated that 8-bromocAMP, a membrane-permeable cAMP derivative, increased NOx production and steady-state iNOS mRNA levels in rat VSMC in a time- and dose-dependent manner (6-24 $\mathrm{h}$ and $10^{-4}-10^{-3} \mathrm{M}$, respectively). The time courses of NOx production and iNOS mRNA induction by cAMP appear to be similar; expression of iNOS mRNA and NOx production were detected after $6 \mathrm{~h}$ and increased during 12-24 h. Such a long time

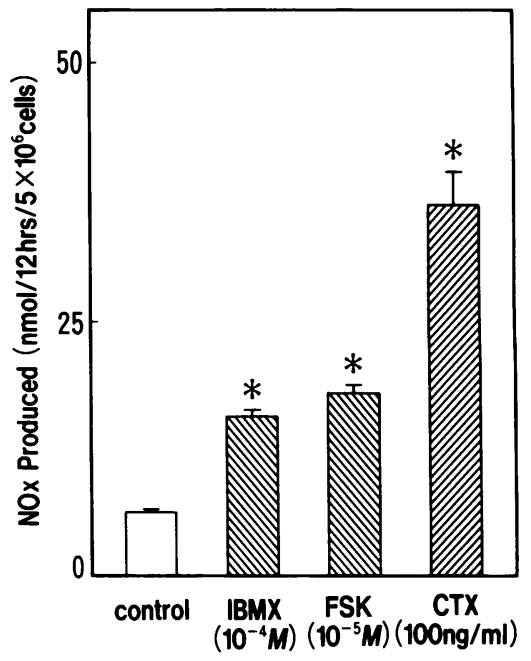

Figure 4. Effect of cAMP-generating agonists on NOx production in rat vascular smooth muscle cells. VSMCs were incubated with $10^{-4} \mathrm{M}$ IBMX, $10^{-5} \mathrm{M}$ forskolin $(F S K)$, and $100 \mathrm{ng} / \mathrm{ml}$ cholera toxin (CTX) for $12 \mathrm{~h}$; NOx released into medium was measured. Data are plotted in the same as in Fig. $2(n=3) .{ }^{*} P<0.05$ vs control. 
A

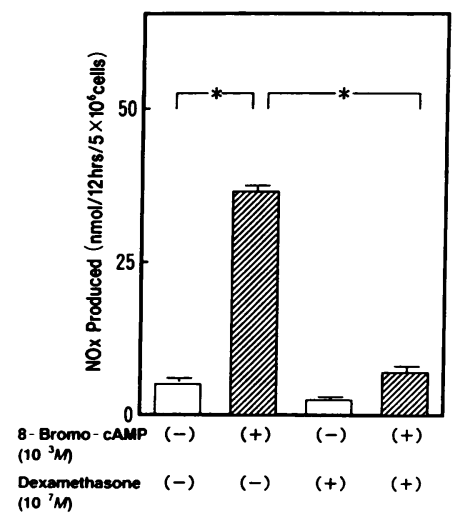

B

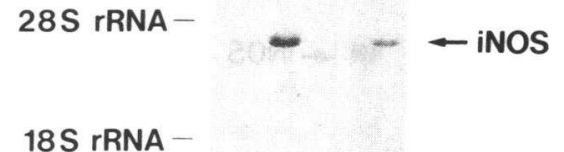

$28 S$ rRNA -
Figure 5. Effect of dexamethasone on 8-bromocAMP-induced NOx production and iNOS mRNA expression in rat vascular smooth muscle cells. $(A)$ VSMCs were incubated with (国) or without ( $\square$ ) 8bromo-cAMP $\left(10^{-3} \mathrm{M}\right)$ in the absence and presence of $10^{-7} \mathrm{M}$ dexamethasone (DEX) for $12 \mathrm{~h}$ for measurement NOx and for $6 \mathrm{~h}$ for Northern blot analysis. Data are plotted in the same as in Fig. $2(n=3) .{ }^{*} P$ $<0.05$ between groups. $(B)$ Northern blot analysis of iNOS mRNA (upper panel) and 28S ribosomal RNA (lower panel) are shown. Lane 1 , control; lane 2, 8bromo-cAMP; lane 3, DEX; lane 4, 8-bromo-cAMP plus DEX. required for the induction of iNOS mRNA and subsequent NOx production by CAMP in rat VSMC appears to be comparable to that of the cytokines-induced production of $\mathrm{NO}$ by mouse macrophages (13) and rabbit VSMCs (6).

The inhibitory effect by L-NMMA, a stereospecific NOS inhibitor, on the 8-bromo-cAMP-induced NOx production and partial reversal of this effect by an excess $\mathrm{L}$-arginine, but not by $\mathrm{D}$-arginine, as demonstrated in this study, is consistent with the notion that cAMP directly stimulates NOS activity to generate NO by catalyzing L-arginine as a substrate in VSMC. However, the reason why an excess substrate of $L$-arginine could not completely reverse L-NMMA-induced inhibition of NOx production by cAMP remains unknown. Such a partial reversal effect by L-arginine on L-NMMA-mediated inhibition of NOx production by cytokines has already been observed in several cultured cells, including rat VSMC (18), porcine endocardial cells (23), and human hepatocytes (24). Recently, it has been reported that L-NMMA can act as an irreversible inactivator of macrophage iNOS by covalent binding of its metabolite(s) to the enzyme (25). Thus, it is possible to speculate that L-NMMA may interact with iNOS molecule too tightly to be replaced by excess $\mathrm{L}$-arginine in rat VSMC.

The present study has also shown that induction of iNOS mRNA and NOx production by 8-bromo-cAMP were inhibited by dexamethasone. These data are in accordance with the previous reports that dexamethasone inhibits the cytokine-in- duced NOS activity and NOx generation in mouse macrophage (26) and porcine endothelial cells (27). However, the present result with incomplete inhibition on induction of iNOS mRNA, but complete blockade on NOx production by dexamethasone implies that glucocorticoids may have posttranslational inhibitory effect on iNOS enzyme activity other than iNOS gene expression. In sepsis syndrome, many chemical mediators, such as cytokines, leukotrienes, and prostaglandins, have been considered to be involved in the development of endotoxin shock (28). The induction of iNOS in the vessel wall including macrophages, endothelial cells, and VSMC may contribute to the development of hypotension and hyporesponsiveness to vasoconstrictors associated with endotoxin shock. In fact, we have recently shown that dexamethasone inhibits the IL- $1 \beta$-induced iNOS mRNA and NOx production in cultured rat VSMC (18). Furthermore, it has been recently reported that dexamethasone has inhibitory effect on the cytokine-induced iNOS mRNA in rat hepatocytes (29). Taken together, the present results lend strong support to the observation that glucocorticoids can prevent hypotension and restore the vascular responsiveness in endotoxin shock (30).

It has been reported that cAMP plays an intracellular role as a second messenger for IL- $1 \alpha$ and IL- $1 \beta$ in human natural killer-like cell line (YT) and murine thymocytes (31). Therefore, it is suggested that cAMP may be one of the intracellular second messengers for IL- $1 \beta$ in rat VSMC to induce iNOS

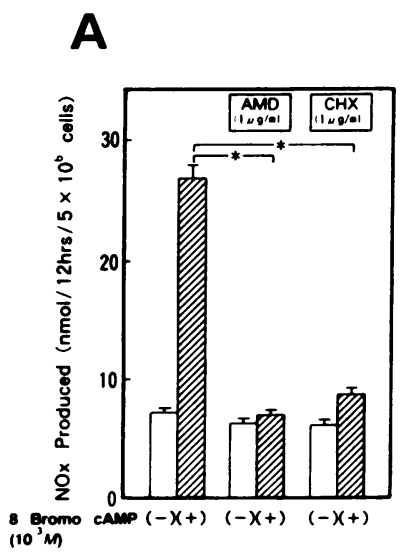

B

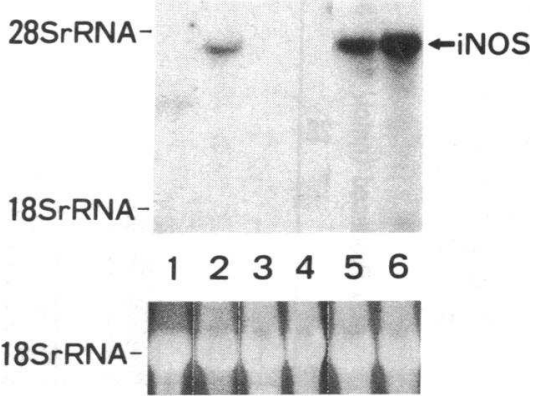

Figure 6. Effects of actinomycin D and cycloheximide on 8-bromo-cAMP-induced NOx production and iNOS mRNA expression in rat vascular smooth mus-

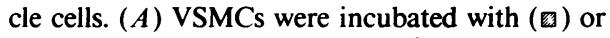
without ( $\square$ ) 8-bromo-cAMP $\left(10^{-3} \mathrm{M}\right)$ in the absence and presence of $1 \mu \mathrm{g} / \mathrm{ml}$ each of actinomycin D $(A M D)$ and cycloheximide $(C H X)$ for $12 \mathrm{~h}$ for measurement of NOx and for $6 \mathrm{~h}$ for Northern blot analysis. Data are plotted in the same as in Fig. $2(n=3)$. ${ }^{*} P<0.05$ between groups. $(B)$ Northern blot analysis of iNOS mRNA (upper panel) and $18 \mathrm{~S}$ ribosomal RNA (lower panel) are shown. Lane 1 , control; lane 2, 8-bromo-cAMP; lane 3, AMD; lane 4, 8-bromocAMP plus AMD; lane 5, CHX; lane 6, 8-bromocAMP plus $\mathrm{CHX}$. 


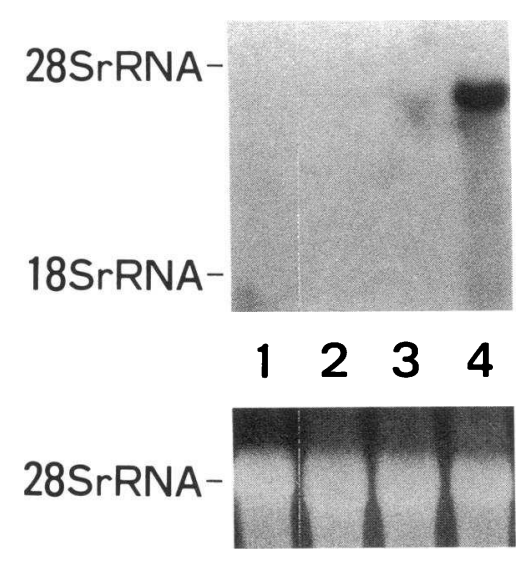

Figure 7. Dose response effect of cycloheximide on iNOS mRNA expression in rat vascular smooth muscle cells. VSMCs were incubated with various concentrations $(0.01-1 \mu \mathrm{g} / \mathrm{ml})$ of cycloheximide ( $\mathrm{CHX}$ ) for $6 \mathrm{~h}$. Northern blot analysis of iNOS mRNA (upper panel) and $28 \mathrm{~S}$ ribosomal RNA (lower panel) are shown. Lane 1 , control; lane $2, \mathrm{CHX}(0.01 \mu \mathrm{g} /$ $\mathrm{ml})$; lane 3, CHX (0.1 $\mu \mathrm{g} / \mathrm{ml})$; lane $4, \mathrm{CHX}$ ( $1 \mu \mathrm{g} / \mathrm{ml}$ ).

mRNA and iNOS synthesis. Our study has further shown that actinomycin D, an RNA transcriptional inhibitor, completely inhibited iNOS mRNA induction and NOx production by cAMP, suggesting the importance of cAMP in the transcriptional regulation of iNOS gene. Cycloheximide, a protein synthesis inhibitor, also completely inhibited the cAMP-induced NOx production. Surprisingly, cycloheximide alone remarkably and dose dependently increased the steady-state levels of iNOS mRNA (superinduction), whose effect was abolished by previous addition of actinomycin $\mathrm{D}$, but not of dexamethasone. Furthermore, the decay in the cycloheximide-induced upregulation of iNOS mRNA after the addition of actinomycin D was not observed during $12 \mathrm{~h}$. Molecular cloning of mouse iNOS ( 12 ) revealed that the 3 '-noncoding region of the mouse iNOS mRNA contains "AUUUA" motif known as a selective mRNA destabilizing sequence (32). An outstanding feature of the specific mRNA degradation process directed by this motif is its sensitivity to mRNA translation inhibitor, cycloheximide. Taken together, it is suggested that cycloheximide stabilizes iNOS mRNA by inhibiting the synthesis of a labile

Figure 8. Effects of dexamethasone and actinomycin D on cycloheximide-induced iNOS mRNA expression in rat vascular smooth muscle cells. VSMCs were incubated with 1 $\mu \mathrm{g} / \mathrm{ml} \mathrm{CHX}$ in the absence and presence of $10^{-7} \mathrm{M}$ dexamethasone or $1 \mu \mathrm{g} / \mathrm{ml}$ actinomycin $\mathrm{D}$ for $6 \mathrm{~h}$. Northern blot analysis of iNOS mRNA (upper panel) and $28 \mathrm{~S}$ ribosomal RNA (lower panel) are shown. Lane 1 , control; lane 2, CHX; lane 3, CHX plus DEX; lane 4, CHX plus AMD. protein $(\mathrm{s})$ responsible for its degradation, leading to a marked accumulation of iNOS mRNA.

It has been reported that $\mathrm{cNOS}$ activated by $\mathrm{Ca}^{2+}$-mobilizing agents, such as bradykinin, endothelin-3, and $\mathrm{Ca}^{2+}$ ionophore, can be augmented by forskolin and phosphodiesterase inhibitor in rodent neuronal cell line (33) and by cholera toxin in porcine endothelial cells (34). Conversely, there are some reports showing that neither a selective cAMP-phosphodiesterase inhibitor ( $\mathrm{AH} 21-132)$, prostacyclin, nor chlorophenylthiocAMP affect the release of NO from bovine endothelial cells (35) or the enzyme activity of purified rat brain cNOS (7). However, there is no information yet available on the regulation of iNOS by cAMP. This is the first report that cAMP plays a key role in the regulation of $\mathrm{NNOS}$ gene in rat VSMC. Upregulation of iNOS mRNA by cAMP is most likely caused by decreased mRNA destabilization and/or increased transcription. To address the former possibility, the decay of cAMP-induced iNOS mRNA was measured by Northern blot analysis. The half-life of the message was $\sim 2 \mathrm{~h}$, which is comparable to that of LPS-induced iNOS mRNA in murine macrophage $(\sim 3 \mathrm{~h})$ (36). Thus, the enhanced expression of iNOS mRNA by cAMP is least likely caused by increased mRNA stability. However, to answer the latter possibility nuclear run-on transcription analysis is needed for the transcriptional control of iNOS gene by cAMP.

It is generally recognized that the second messenger cAMP mediates its hormonal induction of numerous genes through a specific PKA that phosphorylates a $43-\mathrm{kD}$ nuclear phosphoprotein, termed "cAMP response element binding protein," which is a transcriptional factor which binds to a consensus palindromic motif "TGACGTCA", termed cAMP response element, to initiate gene transcription $(37,38)$. Thus, the question as to whether iNOS gene contains cis-acting cAMP response element sequence in the promoter region through which cAMP regulates transcriptional activity needs to be determined by a chloramphenicol acetyltransferase or a luciferase reporter assay.

The present study has shown that various cAMP-generating agonists, including phosphodiesterase inhibitor (IBMX), adenylate cyclase activator (forskolin), and stimulatory guanine nucleotide binding protein regulatory protein activator (cholera toxin), all stimulated NOx production in rat VSMC. These data lend strong support to the contention that an intracellular cAMP plays a second messenger role in the induction of iNOS gene in rat VSMC. VSMC has various receptors for vasodilators, such as $\beta$-adrenergic agonist, calcitonin gene-related peptide, and prostacyclin, through which these agonists can increase intracellular cAMP levels. These agonists cause an immediate vasorelaxation via cAMP-dependent mechanism; PKA phosphorylates membrane $\mathrm{Ca}^{2+}$-ATPase $\left(\mathrm{Ca}^{2+}\right.$ pump) to decrease intracellular $\mathrm{Ca}^{2+}$ levels and myosin light chain kinase to decrease myosin light chain kinase activities $(39,40)$. Our data provide an additional and possible mechanism for the sustained vasorelaxation by these vasodilators via NO production because NO stimulates soluble guanylate cyclase to increase intracellular cGMP levels in VSMC, which in turn activates $\mathrm{Ca}^{2+}$ pump leading to vasorelaxation $(13,41)$. Thus, it is reasonable to speculate that CAMP-induced relaxation of vascular smooth muscle may be mediated by a cross-talk of signal transduction system via cAMP- and cGMP-dependent pathways. 
A

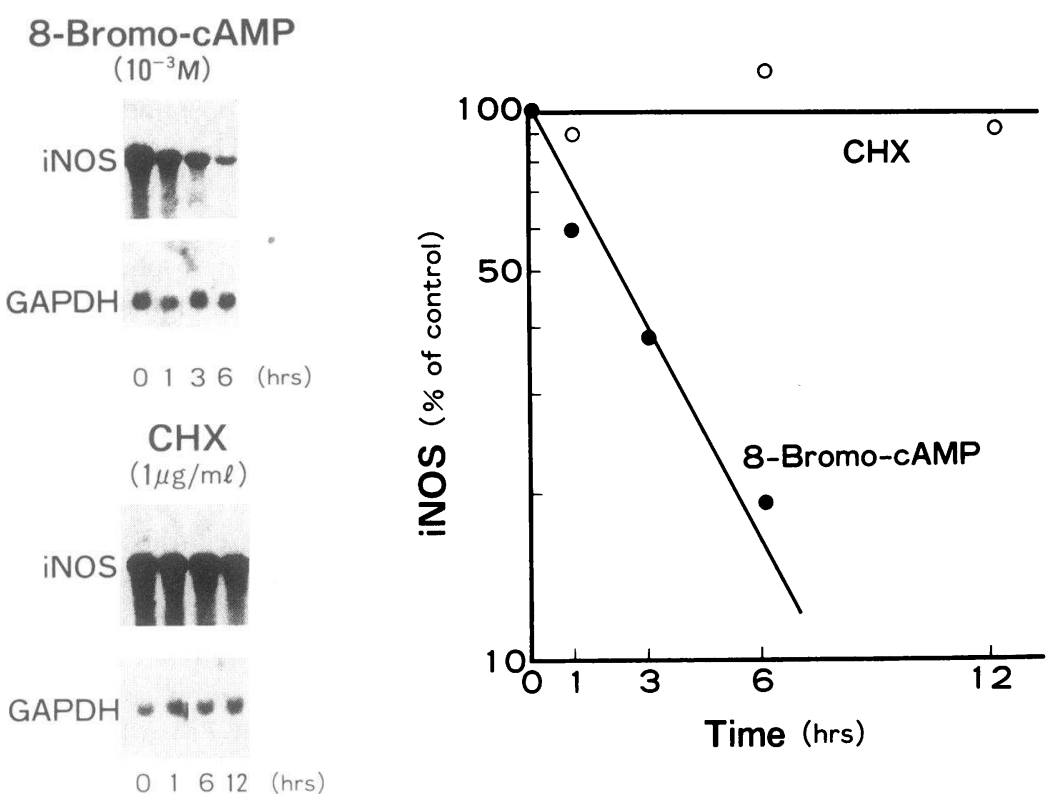

Figure 9. Decay in 8-bromo-cAMP- and cycloheximide-induced iNOS mRNA expression in rat vascular smooth muscle cells. VSMCs were incubated with $10^{-3} \mathrm{M} 8$-bromo-cAMP or $1 \mu \mathrm{g} / \mathrm{ml} \mathrm{CHX}$ for $6 \mathrm{~h}$ before addition of $1 \mu \mathrm{g} / \mathrm{ml}$ actinomycin $\mathrm{D}$ and harvested at the time indicated. $(A)$ Northern blottings of VSMC treated with 8-bromo-cAMP (top) and CHX (bottom) with cDNAs for iNOS (upper lane) and GAPDH (lower lane) as probes are shown. $(B)$ The relative percentage of iNOS mRNA to GAPDH mRNA measured by an imaging analyzer in log scale is plotted against time. •, 8-bromo-cAMP; O, CHX.

\section{Acknowledgments}

This study was supported in part by Grants-in-Aid from the Ministry of Education, Science and Culture (03268102, 03454218, and 03454512) of Japan, and a fund from Uehara Memorial Foundation.

\section{References}

1. Moncada, S., R. Palmer, and E. Higgs. 1991. Nitric oxide: physiology, pathophysiology, and pharmacology. Pharmacol. Rev. 43:109-142.

2. Knowles, R., M. Palacios, R. Palmer, and S. Moncada. 1989. Formation of nitric oxide from $\mathrm{L}$-arginine in the central nervous system: a transduction mechanism for stimulation of the soluble guanylate cyclase. Proc. Natl. Acad. Sci. USA. 86:5159-5162.

3. Mayer, B., K. Schmidt, R. Humbert, and E. Bohme. 1989. Biosynthesis of endothelium-derived relaxing factor: a cytosolic enzyme in porcine aortic endothelial cells $\mathrm{Ca}^{2+}$-dependently converts $\mathrm{L}$-arginine into an activator of soluble guanylyl cyclase. Biochem. Biophys. Res. Commun. 164:678-685.

4. Mulsch, A., E. Bassenge, and R. Busse. 1989. Nitric oxide synthesis in endothelial cytosol: evidence for a calcium-dependent and a calcium-independent mechanism. Naunyn Schmiedebergs Arch Pharmacol. 340:767-770.

5. Hibbs, J. J., R. Taintor, Z. Vavrin, and E. Rachlin. 1988. Nitric oxide: a cytotoxic activated macrophage effector molecule. Biochem. Biophys. Res. Commun. 157:87-94.

6. Busse, R., and A. Mulsch. 1990. Induction of nitric oxide synthase by cytokines in vascular smooth muscle cells. FEBS (Fed. Eur. Biochem. Soc.) Lett. 275:87-90.

7. Bredt, D., P. Hwang, C. Glatt, C. Lowenstein, R. Reed, and S. Snyder. 1991. Cloned and expressed nitric oxide synthase structurally resembles cytochrome P-450 reductase. Nature (Lond.). 351:714-718.

8. Lamas, S., P. Marsden, G. Li, P. Tempst, and T. Michel. 1992. Endothelia nitric oxide synthase: molecular cloning and characterization of a distinct constitutive enzyme isoform. Proc. Natl. Acad. Sci. USA. 89:6348-6352.

9. Sessa, W., J. Harrison, C. Barber, D. Zeng, M. Durieux, D. D’Angelo, K. Lynch, and M. Peach. 1992. Molecular cloning and expression of a cDNA encoding endothelial cell nitric oxide synthase. J. Biol. Chem. 267:15274-15276.

10. Janssens, S., A. Shimouchi, T. Quertermous, D. Bloch, and K. Bloch. 1992. Cloning and expression of a cDNA encoding human endothelium-derived relaxing factor/nitric oxide synthase. J. Biol. Chem. 267:14519-14522.

11. Xie, Q., H. Cho, J. Calaycay, R. Mumford, K. Swiderek, T. Lee, A. Ding, T. Troso, and C. Nathan. 1992. Cloning and characterization of inducible nitric oxide synthase from mouse macrophages. Science (Wash. DC). 256:225-228.

12. Lyons, C., G. Orloff, and J. Cunningham. 1992. Molecular cloning and functional expression of an inducible nitric oxide synthase from a murine macrophage cell line. J. Biol. Chem. 267:6370-6374.
13. Stuehr, D., and M. Marletta. 1985. Mammalian nitrate biosynthesis Mouse macrophages produce nitrite and nitrate in response to Escherichia coli lipopolysaccharide. Proc. Natl. Acad. Sci. USA. 82:7738-7742.

14. Stuehr, D., and M. Marletta. 1987. Induction of nitrite/nitrate synthesis in murine macrophages by BCG injection, lymphokines or interferon- $\gamma$. J. Immunol. 139:518-525.

15. Schini, V., D. Junquero, T. Scott-Burden, and P. Vanhoutte. 1991. Interleukin- $1 \beta$ induces the production of an $\mathrm{L}$-arginine-derived relaxing factor from cultured smooth muscle cells from rat aorta. Biochem. Biophys. Res. Commun. 176:114-121.

16. Hirata, Y., M. Tomita, H. Yoshimi, and M. Ikeda. 1984. Specific receptors for atrial natriuretic factor (ANF) in cultured vascular smooth muscle cells of rat aorta. Biochem. Biophys. Res. Commun. 125:562-568.

17. Kanno, K., Y. Hirata, T. Emori, K. Ohta, S. Eguchi, T. Imai, and F. Marumo. 1992. L-arginine infusion induces hypotension and increases diuresis/ natriuresis with concomitant increased urinary excretion of nitrite/nitrate and cyclic GMP in human. Clin. Exp. Pharmacol. Physiol. 19:619-625.

18. Kanno, K., Y. Hirata, T. Imai, and F. Marumo. 1993. Induction of nitric oxide synthase gene by interleukin in vascular smooth muscle cells. Hypertension (Dallas). 22:34-39.

19. Marchuk, D., M. Drumm, A. Saulino, and F. Collins. 1990. Construction of T-vectors, a rapid and general system for direct cloning of unmodified PCR products. Nucleic Acids Res. 19:1154.

20. Sanger, F., S. Nicklen, and A. Coulson. 1977. DNA sequencing with chain-terminating inhibitors. Proc. Natl. Acad. Sci. USA. 74:5463-5467.

21. Chomczynski, P., and N. Sacchi. 1987. Single-step method of RNA isolation by acid guanidinium thiocyanate-phenol-chloroform extraction. Anal. Biochem. 162:156-159.

22. Imai, T., Y. Hirata, T. Emori, M. Yanagisawa, T. Masaki, and F. Marumo. 1992. Induction of endothelin-1 gene by angiotensin and vasopressin in endothelial cells. Hypertension (Dallas). 19:753-757.

23. Schulz, R., J. A. Smith, M. J. Lewis, and S. Moncada. 1991. Nitric oxide synthase in cultured endocardial cells of the pig. Br. J. Pharmacol. 104:21-24.

24. Nussler, A. K., M. Di Silvio, T. R. Billiar, R. A. Hoffman, D. A. Geller, R. Selby, J. Madariaga, and R. L. Simmons. 1992. Stimulation of the nitric oxide synthase pathway in human hepatocytes by cytokines and endotoxin. J. Exp. Med. 176:261-264.

25. Olken, N. M., K. M. Rusche, M. K. Richards, and M. A. Marletta. 1991. Inactivation of macrophage nitric oxide synthase activity by $N^{\mathrm{G}}$-methyl-L-arginine. Biochem. Biophys. Res. Commun. 177:828-833.

26. Di Rosa, R. M., M. Radomski, R. Carnuccio, and S. Moncada. 1990. Glucocorticoids inhibit the induction of nitric oxide synthase in macrophages. Biochem. Biophys. Res. Commun. 172:1246-1252.

27. Radomski, M. W., R. M. Palmer, and S. Moncada. 1990. Glucocorticoids inhibit the expression of an inducible, but not the constitutive, nitric oxide synthase in vascular endothelial cells. Proc. Natl. Acad. Sci. USA. 87:10043-10047. 
28. Bone, R. 1991. The pathogenesis of sepsis. Ann. Intern. Med. 115:457469.

29. Geller, D. A., A. K. Nussler, M. Di Silvi, C. J. Lowenstein, R. A. Shapiro, S. C. Wang, R. L. Simmons, and T. R. Billiar. 1993. Cytokines, endotoxin, and glucocorticoids regulate the expression of inducible nitric oxide synthase in hepatocytes. Proc. Natl. Acad. Sci. USA. 90:522-526.

30. Schaefer, C., D. Brackett, and M. Wilson. 1983. The benefits of corticosteroid given after the onset of hypotension during endotoxin shock in the conscious rat. Adv. Shock Res. 10:183-194.

31. Shirakawa, F., U. Yamashita, M. Chedid, and S. Mizel. 1988. Cyclic AMP: an intracellular second messenger for interleukin 1. Proc. Natl. Acad. Sci. USA. 85:8201-8205.

32. Shaw, G., and R. Kamen. 1986. A conserved AU sequence from the 3 untranslated region of GM-CSF mRNA mediates selective mRNA degradation. Cell. 46:659-667.

33. Reiser, G. 1992. Nitric oxide formation caused by $\mathrm{Ca}^{2+}$ release from internal stores in neuronal cell line is enhanced by cyclic AMP. Eur. J. Pharmacol. 277:89-93.

34. Boulanger, C., and P. Vanhoutte. 1992. Cholera toxin augments the release of endothelium-derived relaxing factor evoked by bradykinin and the calcium ionophore A23187. Gen. Pharmacol. 23:27-31.
35. Kuhn, M., A. Otten, J. Frolich, and U. Forstermann. 1991. Endothelial cyclic GMP and cyclic AMP do not regulate the release of endothelium-derived relaxing factor/nitric oxide from bovine aortic endothelial cells. J. Pharmacol. Exp. Ther. 256:677-682.

36. Lorsbach, R., W. Murphy, C. Lowenstein, S. Snyder, and S. Russel. 1993. Expression of the nitric oxide synthase gene in mouse macrophages activated for tumor cell killing. J. Biol. Chem. 268:1908-1913.

37. Montminy, M., and L. Bilezikjian. 1987. Binding of a nuclear protein to the cyclic-AMP response element of the somatostatin gene. Nature (Lond.). 328:175-178.

38. Yamamoto, K., G. Gonzalez, W. Biggs III, and M. Montminy. 1988. Phosphorylation-induced binding and transcriptional efficacy of nuclear factor CREB. Nature (Lond.). 334:494-498.

39. Scheid, C., T. Honeyman, and F. Fay. 1979. Mechanism of $\beta$-adrenergic relaxation of smooth muscle. Nature (Lond.). 277:32-36.

40. Stull, J., and D. Blumenthal. 1980. Regulation of contraction by myosin phosphorylation. Biochem. Pharmacol. 29:2537-2543.

41. Karaki, H., K. Sato, H. Ozaki, and K. Murakami. 1988. Effects of sodium nitroprusside on cytosolic calcium level in vascular smooth muscle. Eur. J. Pharmacol. 156:259-266. 